\title{
134 長柱の軸衝撃エネルギー吸収に及ぼす横衝撃の影響
}

Effect of transverse impact on axial impact energy absorption of column

\author{
○アズハリサストラネガラ（東工大院） 正足立 忠晴（東工大院） 正山路 昭彦（東工大院）
}

Azhari SASTRANEGARA, Tokyo Institute of Technology, 2-12-1 O-okayama, Meguro-ku, Tokyo

Tadaharu ADACHI, Tokyo Institute of Technology, 2-12-1 O-okayama, Meguro-ku, Tokyo

Akihiko YAMAJI, Tokyo Institute of Technology, 2-12-1 O-okayama, Meguro-ku, Tokyo

Key words: Impact, Energy Absorption, Crashworthiness, Buckling Control

\section{1. 緒言}

衝突事故において輸送機械の乗員の安全を確保するた めに，構造を压潰させることにより衝撃エネルギーを吸 収することが行われている。このために車体構造および, その基本構造の衝撃エネルギー吸収に関する研究は今ま でに多数行われている. 実際の車体においては潰れビー ドと呼ばれる切欠きを構造に設けたり, 曲げられた構造 などを用いてエネルギー吸収効率を高めている(1) (2). こ礼らは基本的には構造の剛性を低下させて座屈もしく は圧潰を容易に生じさせるものである。これに対して高 速で移動する輸送機械の重要な運動性能を得るためには 高い車体剛性が要求される。このような車体運動性能と 衝撃エネルギー吸収効率を適切に満足するように輸送機 械の剛性が設定されているのが現状である.

本研究では潰れビードなどのように, あらかじめ構造 の剛性を低下させることなく衝繋時において外力により 構造の剛性を低下させてエネルギー吸収効率を向上させ る方法について検討する。すでに著者らは横衝擊により 長柱の軸方向の衝輷エネルギー吸収を增加させることを 実験的に実証した(3)。本報告では有限要素法により長 柱の衝暂エネルギー吸収に及ぼす横衝转の影響を検討し， 実験結果を確認する。吸収エネルギーに及ぼす横衝撃の 作用時間および軸衝慗に対して横衝撃の加える時間の影 響について考察する。

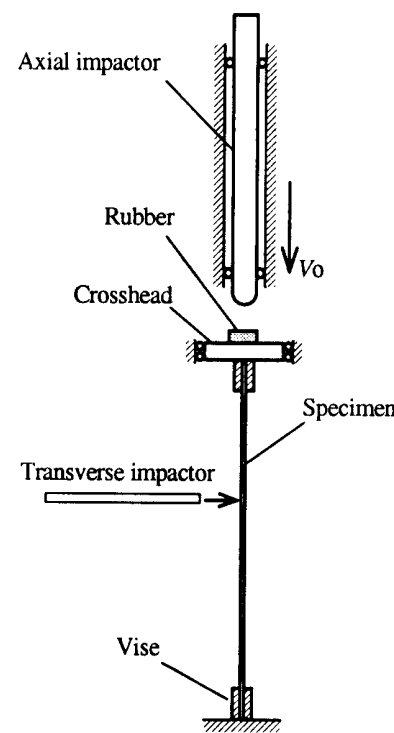

Experimental model

(a)

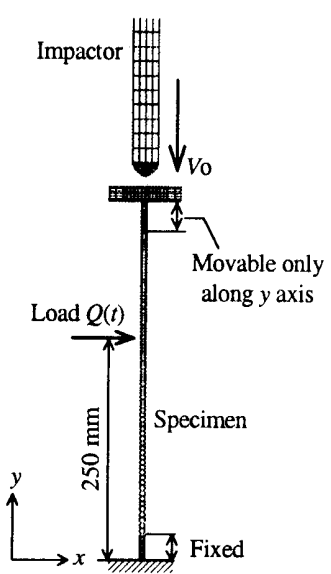

Simulation model

(b)
Figure 1 Outline of simulation model

\section{2. 計算の概要}

研究において対象としたモデル Fig.1 に示す。 Fig.1(a)は実験装置の概要であり，Fig.1(b)は有限要素法 で使用したモデルである、本報告の計算ではクロスヘッ ド上面の置かれたゴム層を無くし，軸衝撃棒の弾性率を 小さくし軸衝撃の作用時間が長くなるようにした。計算 モデルのそれぞれの材料特性を表 1 に示す.

表 1 有限要素法モデルの諸元

\begin{tabular}{ccccccc}
\hline Part & $\begin{array}{c}E \\
{[\mathrm{MPa}]}\end{array}$ & $\begin{array}{c}P \\
{\left[\mathrm{~kg} / \mathrm{m}^{3}\right]}\end{array}$ & $v$ & $\begin{array}{c}y \text {-length } \\
{[\mathrm{mm}]}\end{array}$ & $\begin{array}{c}x \text {-width } \\
{[\mathrm{mm}]}\end{array}$ & $\begin{array}{c}\text { Sectional } \\
\text { area }\left[\mathrm{mm}^{2}\right]\end{array}$ \\
\hline Impactor & 0.28 & 7850 & 0.3 & 750 & 35 & 1260 \\
Crosshead & 210 & 7850 & 0.3 & 200 & 100 & 10000 \\
Specimen & 70 & 2700 & 0.3 & 400 & 3 & 60 \\
\hline
\end{tabular}

速度 $V_{0}$ で衝擊棒をクロスヘッド部に衝突をさせて， 生じる軸衝撃が作用中に横から動的荷重 $Q(t)$ を加える. Fig.2に示されるように実験 ${ }^{(3)}$ から得られる横衝撃荷重 の近似であり，次式で与える.

$$
Q(t)= \begin{cases}\frac{1}{2} \cos \frac{2 \pi}{T}\left(t-t_{\mathrm{T}}\right) & t_{\mathrm{T}}<t<t+t_{\mathrm{T}} \\ 0 & 0<t<t_{\mathrm{T}}, t>t_{\mathrm{T}}\end{cases}
$$

ここで $t$ は時間， $T$ は横荷重の作用時間， $t_{\mathrm{T}}$ は軸衝撃が 開始した時点から横荷重が作用するまでの時間である. 横荷重の作用点は試験片下端より $250 \mathrm{~mm}$ とした。数値 計算は汎用有限要素法プログラム MARC ver. K7 で行っ た.

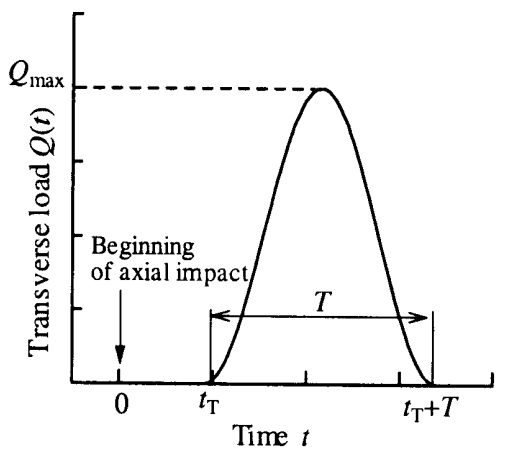

Figure 2 Transverse load $Q(t)$

\section{3. 解析結果}

軸衝撃速度を $V_{0}=2.8 \mathrm{~m} / \mathrm{s}$ としたときの軸衝撃荷重, 試験片上端の変位およびエネルギー吸収の時間変化を Fig.3に示す. Fig.3 (a) は横衝擊の作用時間 $T$ が $1.0 \mathrm{ms,}$ 最大荷重 $Q_{\max }$ が $500 \mathrm{~N}$ であり，Fig.3 (b) ではそれぞれ 
$T=0.4 \mathrm{~ms}$ と $Q_{\max }=250 \mathrm{~N}$ である. 両図において横衝繋 を加えない場合は最大荷重が約 $5.3 \mathrm{k} \mathrm{N}$, 軸衝慗の作用 時間が約 $8 \mathrm{~ms}$ となっている. 横衝撃を加えることで軸 衝撃の最大荷重は减少し，作用時間はほとんど変化しな いことがわかる．Fig.3 の二つの条件においてでは軸衝 揧荷重の最大值が $30 \%$ 減少し, 試験片上端の変位が約 1.8 倍に大きくなった。 また同図から軸荷重 $P$ と試験片 上端の変位 $u$ の関係から次式によりエネルギー吸収 $E_{\mathrm{ab}}$ を求めた。

$$
E_{\mathrm{ab}}=\int_{0}^{u_{T}} P(u) d u
$$

ここで $u_{\mathrm{T}}$ は衝突が終了した時の変位である.

Fig.3のいずれの結果とも，軸衝撃とほぼ同時に横衝撃 を作用させた場合 $(t \mathrm{~T} \fallingdotseq 0 \mathrm{~ms})$ がエネルギー吸収が高く なった。 また, 横衝撃時間が遅そくなるとともにエネル ギー吸収があまり増加しないことが分かった。この結果 は実験で得られた結果 ${ }^{(3)}$ と一致している.
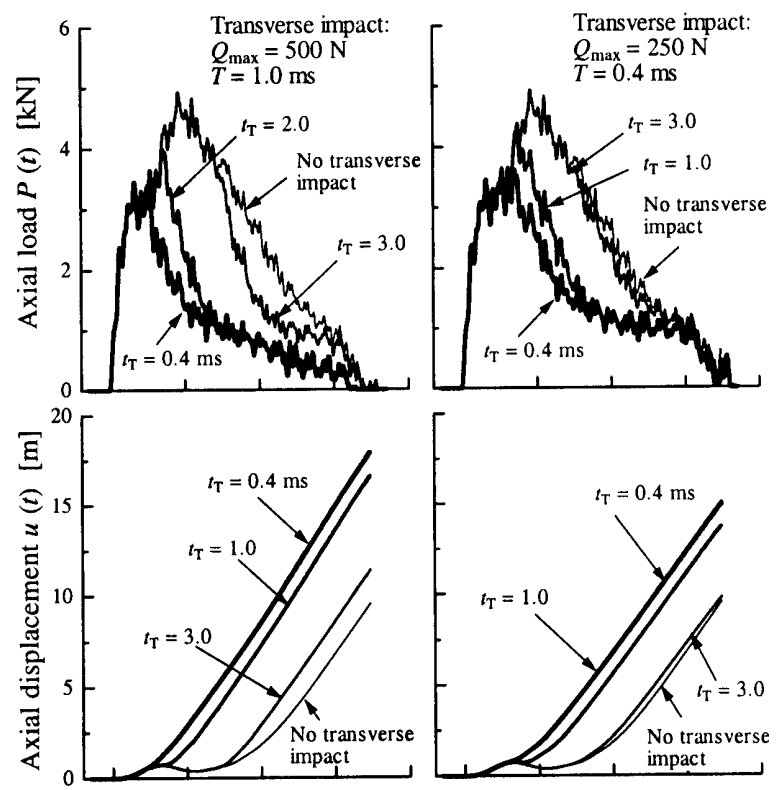

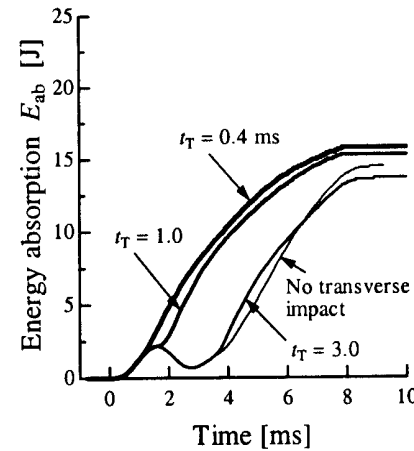

(a)

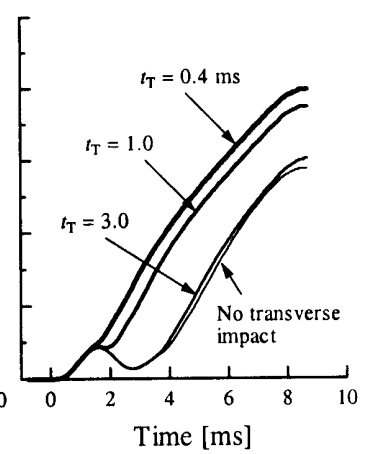

(b)
Figure 3. Simulation results. Axial impact velocity $V_{0}=2.8 \mathrm{~m} / \mathrm{s}$

Fig.4に横衝撃時間 $t_{\mathrm{T}}$ とエネルギー吸収 $E_{\mathrm{ab}}$ の関係を 説明する。ここでエネルギー吸収率は軸衝撃棒の衝撃直 前の運動エネルギーに対する吸収エネルギーの比である. Fig.4(a) から, 横衝撃時間 $t_{\mathrm{T}}=0.4 \mathrm{~ms}$ の時はエネルギー 吸収量は最大となった。また, 横衝撃荷重の最立ち $Q_{\max }$ が $100 \mathrm{~N}$ の時はエネルギー吸収量が最大となり, $Q_{\max }$ が $1000 \mathrm{~N}$ の時はエネルギー吸収が横衝撃を加え ない場合より低くなった。 すなわち大きな横衝撃を加え
ることで長柱の剛性が過剩に低下するため吸収エネルギ 一も低下したと考えられる.Fig.4(b)では横衝撃荷重の 作用時間の短い場合 $(T=0.4 \mathrm{~ms})$ の結果を示す.このと き $Q_{\max }=1000 \mathrm{~N}$ でも吸収エネルギーが増加している.

Fig.5 には横衝撃の作用時間 $T$ および横衝撃時間 $t_{\mathrm{T}}=$ $1.0 \mathrm{~ms}$ ，最大エネルギー吸収と $Q_{\operatorname{maxt}}$ の関係を示す. $Q_{\max }$ が低くなるとエネルギ一吸収が増加するが， $Q_{\max }$ が小さい範囲で最大值が存在することがわかる。

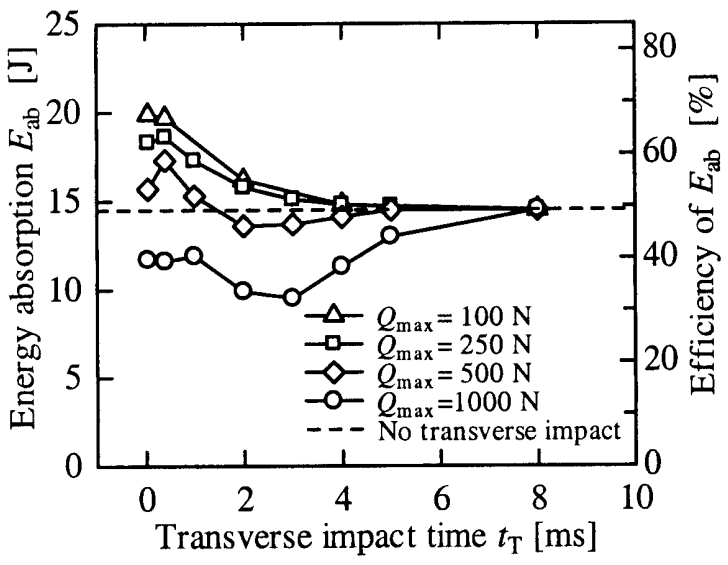

(a) Impact duration $T=1.0 \mathrm{~ms}$

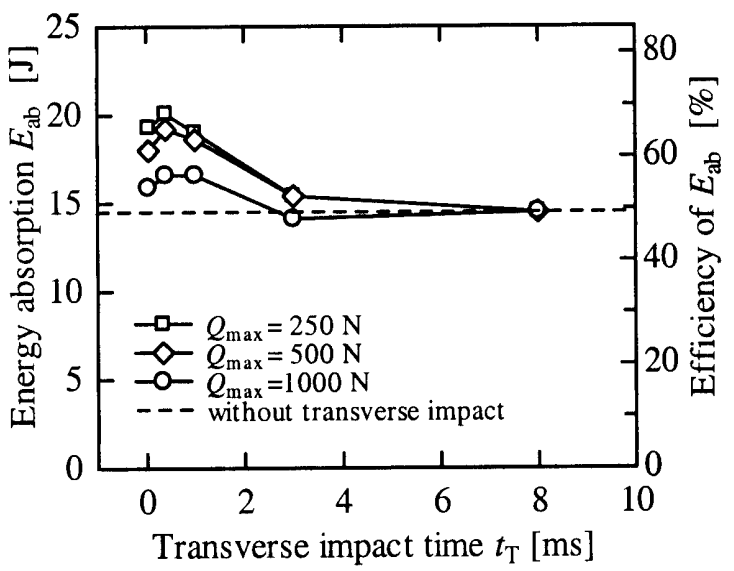

(b) Impact duration $T=0.4 \mathrm{~ms}$

Figure 4. Relation of $E_{\mathrm{ab}}$ and $t_{\mathrm{T}}$

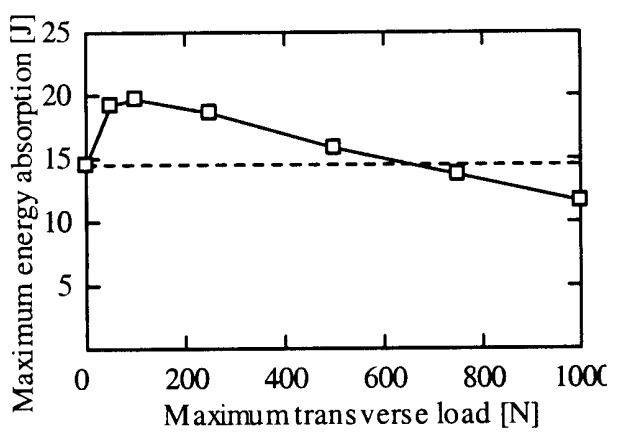

Figure 5. Relation of $E_{\text {ab }}$ and $Q_{\max }$ Impact duration $T=1.0 \mathrm{~ms}$

4. 文献

1) Alghamdi AAA. Collapsible impact energy absorbers: an overview. Thin-Walled Structures 2001; 39: 189-213.

2) N. Jones, Structural Impact, (1989), Cambridge

3) アズハリら，長柱の軸衝撃エネルギーに及ぼす 横衝撃の影響, 日本機械学会材料力学部門講演 会講演論文集, No. 02-05, (2002), pp.675-676 